\title{
TRPM7/CYP19A1 Fusion Gene
}

National Cancer Institute

\section{Source}

National Cancer Institute. TRPM7/CYP19A1 Fusion Gene. NCI Thesaurus. Code C99700.

A fusion gene that results from a complex chromosomal rearrangement of the $q$ arm of chromosome 15 where exon 1 of the TRPM7 gene is fused with exon 2 of the CYP19A1 gene. This fused gene causes increased expression of the CYP19A1 gene and is associated with aromatase excess syndrome. 